\title{
Traditional Caddo Potter
}

Chase K. Earles

Unknown

Follow this and additional works at: https://scholarworks.sfasu.edu/ita

Part of the American Material Culture Commons, Archaeological Anthropology Commons, Environmental Studies Commons, Other American Studies Commons, Other Arts and Humanities Commons, Other History of Art, Architecture, and Archaeology Commons, and the United States History Commons

Tell us how this article helped you.

This Article is brought to you for free and open access by the Center for Regional Heritage Research at SFA ScholarWorks. It has been accepted for inclusion in Index of Texas Archaeology: Open Access Gray Literature from the Lone Star State by an authorized editor of SFA ScholarWorks. For more information, please contact cdsscholarworks@sfasu.edu. 
Traditional Caddo Potter

Creative Commons License

(c) $($ ) $(9)$

This work is licensed under a Creative Commons Attribution-NonCommercial 4.0 International License 


\title{
Traditional Caddo Potter
}

\author{
Chase Kahwinhut Earles
}

Although I originally set out to find an art form that I was comfortable with and would be inspired by, for myself, I ended up discovering an ancient art form that would benefit not just myself, but the generations of Caddo people that would come after me. I feel that eventually they will see the benefit from its rediscovery. But also, I quickly realized the need to make public the distinction of our ancient pottery legacy for the sake of those Caddo that would pick up the craft. The Native American art world in the American Southeast is much different from that of the Southwest that I grew up loving. So many Native American artists are confused about what is their tribe's specific legacy and traditional art form that many claim a broad spectrum of tribes in the region by creating artwork under the umbrella of "Mississippian" or "Southeastern Ceremonial." It became apparent that the Caddo's specific and unique pottery heritage is in danger of being misrepresented in the art world and to collectors. Making it all the more obvious was that I found out there was only one active Caddo member practicing pottery making, Jereldine Redcorn. I felt like although she was successful in reviving the lost art of our Caddo pottery, there is only so much one person can do and it was then that I decided that I could help expand and help spread our knowledge and our experiences so that our beautiful pottery tradition could be reborn and survive for all time, rather than become lost again in the earth.

As a child my family would take me on vacations to the Southwest, New Mexico, Arizona, Utah, and Colorado, almost every year during the summer for school break. We visited places like Old Town, New Mexico, Santa Fe, New Mexico, Durango, Colorado, Mesa Verde, Colorado, Sedona, Arizona, Tlaquepaque, Arizona, and many other places. I grew fond of the culture of the Southwest, particularly as it pertained to art, and learned quite a bit about it. I was an artist growing up, drawing and painting feverishly, partly for myself, but partly to please my teachers of art. My art was definitely influenced by the Southwest's style, which was definitely influenced by the culture and history of the Native Americans and Pueblo Indians. I remember going on trips making notes of what would be cool to try to mimic or create when I got home. It was inspiring, yet mimic here, is the key word.

Later on in life, after getting married, we went on a vacation to the Southwest along the same familiar routes and I realized that I loved the sculpture and the pottery. I started really taking a look at the Pueblo pottery and the stylized sculptures from the independent artists that displayed their work in the many galleries. Again, I started taking notes and making scribbles of things I would love to create when I got home. Although I never physically realized any of those ideas, I was definitely inspired. Could I have started creating something immediately, I surely would have. Life seems to have other ideas. It is not necessarily that I never got around to it; it is more like there were more pressing matters or financial things to work out before I could start "playing in the mud." I discovered early on that art is a luxury, so it is the last to come and the first to go. For me, I might like to strive to make it more than that.

I had not created any art, drawing, painting, or sculpture since college. It had been almost 10 years now. I felt like I had lost touch with any inspiration to create art. I questioned why there was no inspiration any more, no desire to create any art. I liked building things, I could always create things with my hands, but I felt that artistic expression was not there any more. Finally in 2011, we went on another vacation and I was inspired even more. We had just moved out onto our own property with two acres of land with a creek and trees, and I felt it was the perfect place to start working on my art. I made note of every pot I came across, Acoma, Zuni, Ildefonso, and many others. I asked many questions and started researching the way to create 
these works of art by myself, for my very own. I learned how they made the clay. I learned how they formed the pots. I learned how they decorated them, and how they painted them with boiled beeweed. I learned how they burnished the pots to a fine polish. I learned how they fired the pots using semi-traditional methods of pit and smoke firing. There were so many questions, I started learning quickly from many different sources. I bought some clay, and some Rocky Mountain beeweed, and gathered wood. I wanted to start right away.

But, I never started. Something plagued me so much so that I could not bring myself to make a space for my pottery and actually start sculpting something or anything. It did not feel important to me. It did not matter very much, but I did not know why. After being so inspired, I did not know why I was so indifferent now. Whether there was a new video game out to play or a new television show to watch, the act of crafting pottery for art just did not stay appealing for very long. I would always find ways to pass the time and ignore that nagging in me that wanted to start my art back up again and create something special. Finally, I realized what the problem was and it was profound. I realized that I had no real connection to the Pueblo pottery that I aspired to create. They would be cool to make, and pretty, but they would not be special. They would not be worth anything to me emotionally, for all the effort I would be putting into them, and they certainly wouldn't be worth anything financially either as they would merely be "knock-offs" of real traditional pottery made by the Pueblo people. They would be simply replicas and not art. I am not a Pueblo Indian. I instantly gained a respect for the Pueblo peoples' awesome history and culture that they possess and felt that it would be obviously insulting to those people to unwittingly fake and replicate their meaningful works of art that are their voice and their record that will forever preserve their people. I decided that to create my own artwork if would have to be my voice and would have to have real reason or else it would be empty, and furthermore to copy a different tribe's unique tradition would be unethical. So I looked inward at my own heritage and my own tribe's culture. And it did not take long. I was surprised by the richness of our tradition.

Kumbakihah Kawinhut. That is how you say "My name is Kawinhut" in Caddo. I was named by Julia Edge, an influential elder of the White Bead's of the Caddo tribe (Figure 1). I was always interested in my culture, my tribe, and my heritage, but it took longing for a voice in artistry to start posing questions. My first was, "Did the Caddo's make pottery?" I thought to myself, I wonder if we ever had a tradition of pottery? Surely we did. It seems like most ancient or older societies made some form of pottery. A little naive, I thought, surely since I had never heard of any Caddo pottery, it must have been crude, unskilled, insignificant, or surely it would not be rich in depth, style, form, or historic significance. Surely it could not be anything like the grandeur of

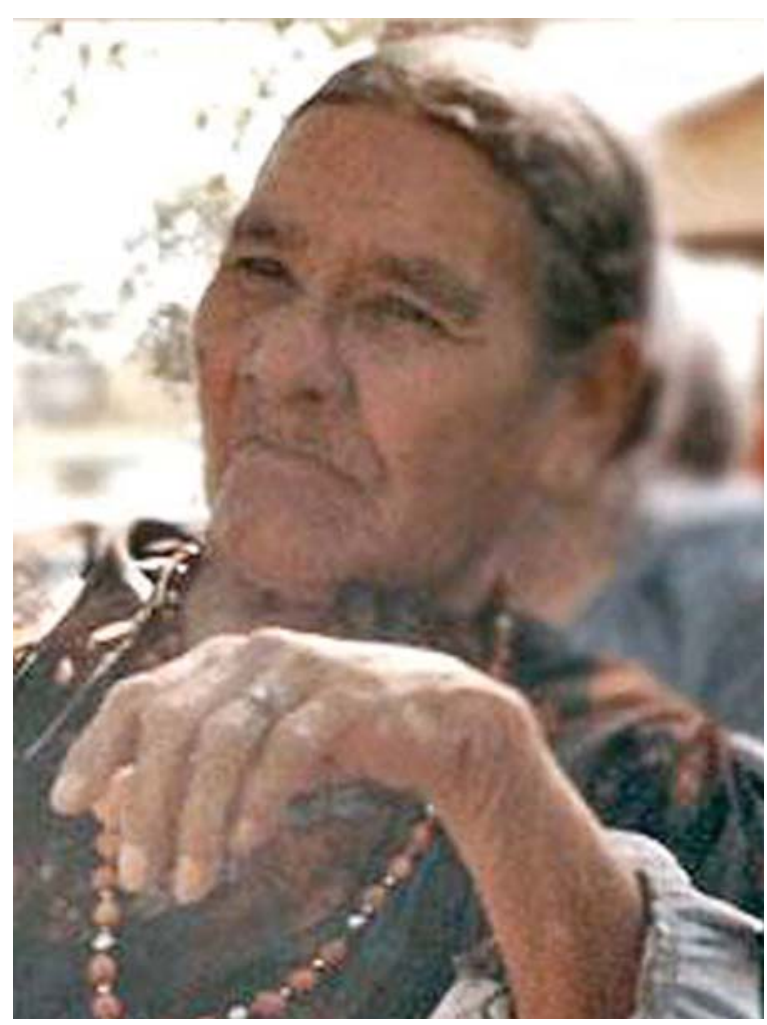

Figure 1. Julia Edge. the Pueblo tradition of pottery.

The utterly contrasting truth was so startling and so overwhelming. I had no idea what the Caddo people created and were known for creating. How would I have known? I felt like it might be because I grew up so far removed from my culture or tribe, that maybe it was something I missed out on or that it was something I was not taught. However, another contrasting truth is that hardly any Caddos know about the wealth of their ceramic heritage and culture. Apparently we created one of the most enormous breadths of finely 
skilled pottery. Apparently there are a wide number of museums with collections of ancient Caddo pottery. Jeri Redcorn (Figure 2) eventually told me there are museums in Europe with our ancestor's pottery, and that she recently had a gallery showing in Germany. The ancient pottery was traded during colonization of North America. Apparently the pottery of the Caddo homelands was some of the most refined and sought after pottery in all of the land at the peak of their civilization.

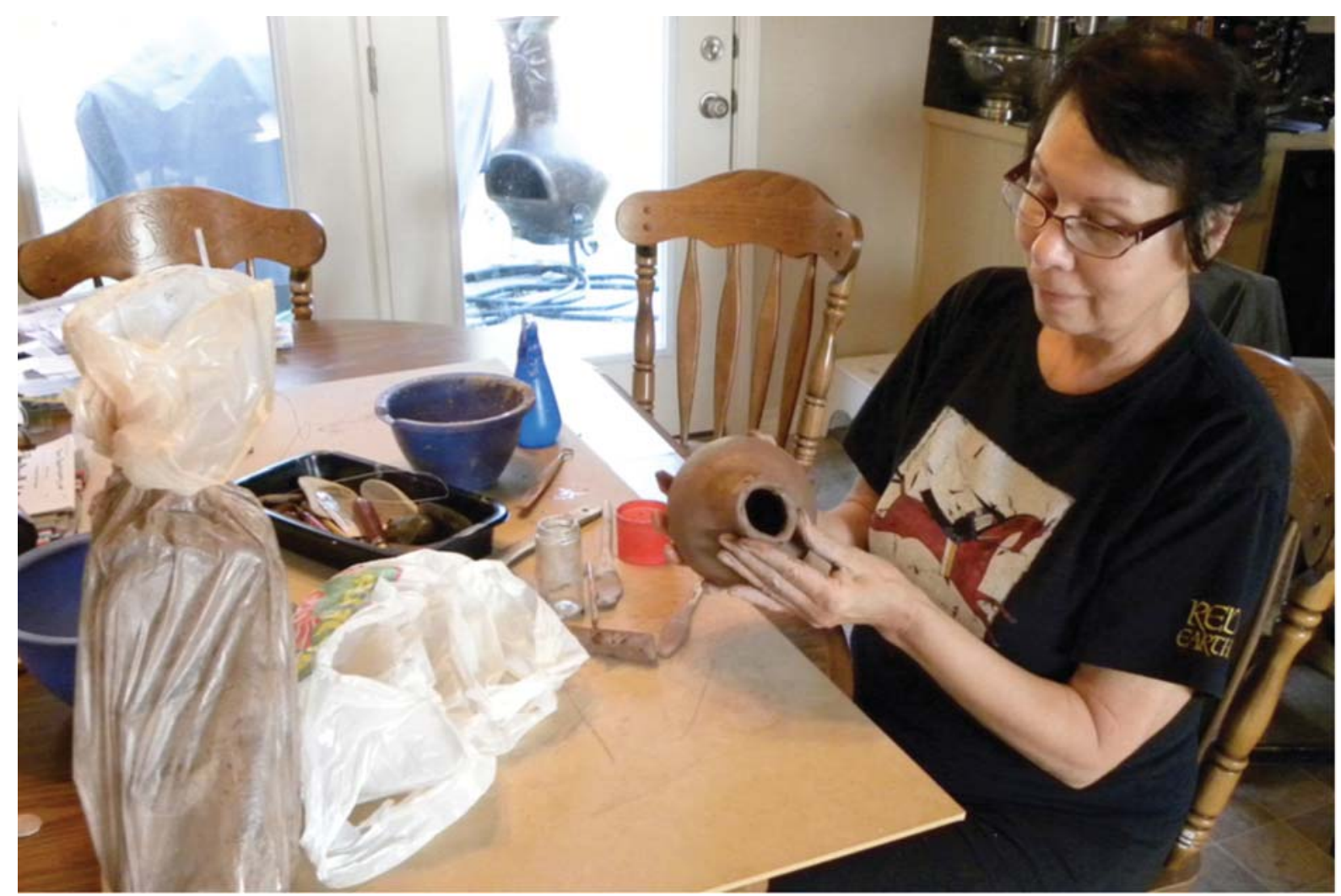

Figure 2. Jeri Redcorn.

I wondered if anyone still possessed these skills and this knowledge. I wondered where all our culture and the history surrounding it went, and if it was lost. I immediately started searching as I assumed it was going to be quite a long and hard sort of investigation. However, I ended up searching on Google and it did not take long at all to find out about Jereldine Redcorn. She had posed a lot of the same questions I had, and alone set out one day and revived the tradition of Caddo pottery. She had done so much research with archaeologists, museums, historical accounts, books, and more books, to figure out, on her own, how to create pottery like our ancestors. Well, at that instant I knew. I had found my calling and found my voice. I was a Caddo Indian and I was going to help revive and advance the traditions and history of Caddo pottery so that it could be carried on and not lost. For the first time in my life I felt like I really had a reason to create art, and a voice behind which to inspire it. This would be something real, and something meaningful.

I wanted to talk to Jeri right away, of course. I have learned that I had no patience, and with that realization, I thought to myself, learning to create clay, pots, and firing the correct way, even this whole process, is going to require a lot of patience. Upon contacting her I found out right away that I was related to her from one of our distant relatives, an Edmond. A common saying among Caddos is that we are all cousins. The following week we were able to meet for lunch and talk at great length about the history of Caddo pottery, and about creating and firing it, designs, and inspiration. It seemed like there was not enough time. There were too many subjects to cover and not enough time. 
Quickly, but not without much debating and deliberation, I came to the conclusion that being an artist and being an Indian artist are not exactly the same things. This is something that I think a lot of people do not realize or even think about, but it affects everything the Indian artist does from materials and methods, to research, and marketing.

From my formal education in fine arts, I learned that a true artist stands alone. They are judged by their peers merely on the quality, craftsmanship, and beauty of their art. Their decisions and their statements in their work are their own and formulated solely from their own mind. They do not get the benefit of being grouped with an internationally familiar group or given exclusive entrance into competition and exhibitions, nor are they granted the honor of having pieces requested for museums or official collections without their art standing on its own unattached to any connotation or ethnicity. It is very different for an Indian artist. If an artist chooses to acknowledge their native heritage and culture in their artwork and publicly announce it, then they automatically become representatives of that tribe, whether they like it or not. I could say I was making pottery without ever saying it was Native American or Caddo pottery, and it could be beautiful and I could possibly be successful or enter galleries and never mention my tribal affiliation. But the minute I decided to publicly acknowledge that I am Caddo and that I am going to be creating Caddo pottery, is the minute I became a representative for my tribe, and became responsible for representing the traditions and culture of my tribe honestly, accurately, and unselfishly.

I feel like it is then my responsibility to learn and understand what is inherently traditional about my tribe's arts, promote it, and represent it to the best of my abilities. It should also be marketed and described correctly and as accurately as possible. Upon my acceptance as a Native American artists or as a Caddo potter I feel like it is then my duty to take these responsibilities seriously as I am afforded the benefits of being a Caddo representative and a Native American and not merely an independent fine artists with no guidelines that describe and define my people's heritage and culture. I am setting an example for all of my Caddo people then and not just of myself. Because of that, I feel like I should be true to myself and to my people and to the public about what is traditional and what is contemporary of the Caddo Nation. With this in mind, I set out to learn as much as I could. It was almost as a feverishly obsessive quest that I leaped into discovering everything that was known about the Caddo's prehistory as it pertained to pottery, the designs and their meanings, the substance of the clay, and the tried and true methods of finishing and firing. Although I have read over 100 books now that pertain to the Caddo, Southeast Indians, pottery, and ceramic techniques, it

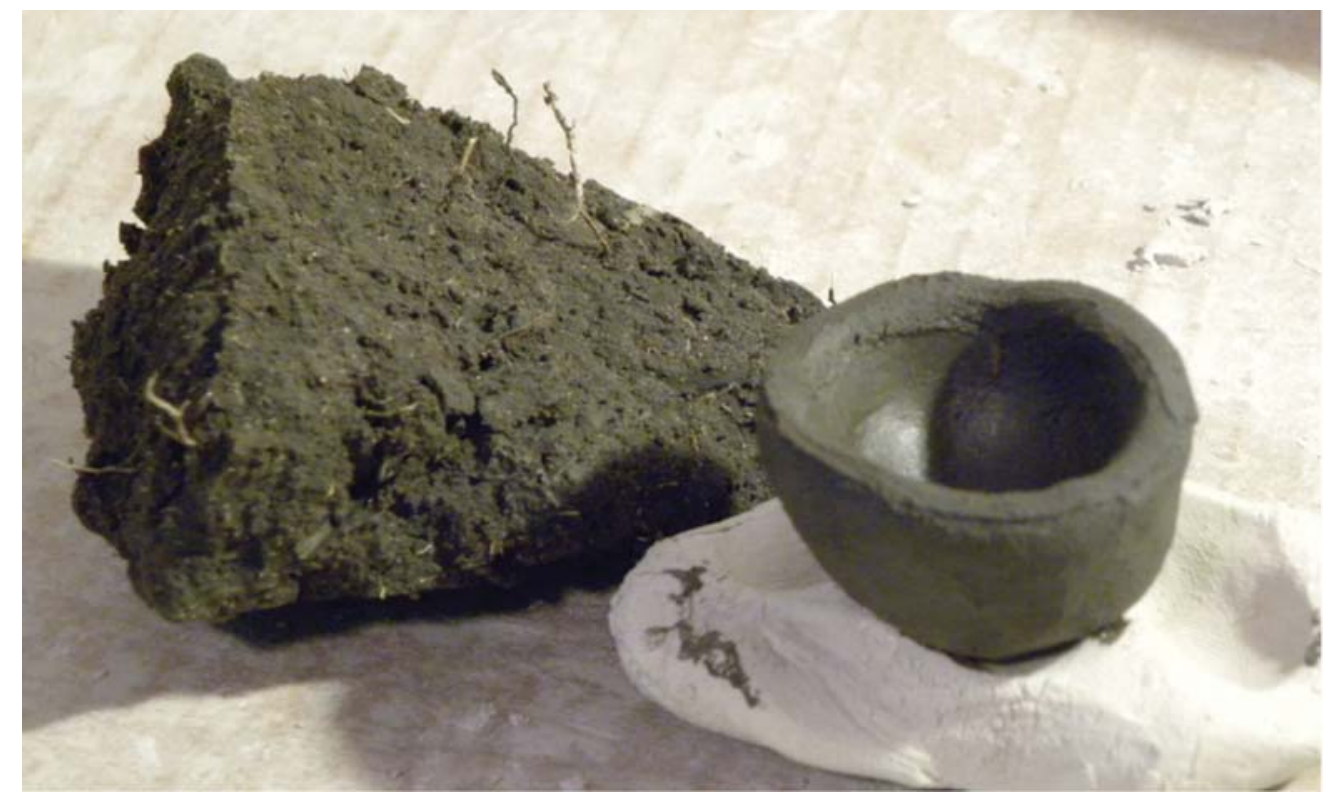

Figure 3. Local raw clay. 
would became trial and error, and personally divulged methodologies that ultimately taught me the most about the creation of Caddo pottery.

While I did immediately start using commercially produced clays because that is what I had readily available to me, I finally did start using traditional clays, but not necessarily local clays all of the time (Figure 3). The Caddos would find and use what was the easiest and best quality clay around them rather than carry it for miles. However, I did want to use the clays our ancient ancestors used that were from the same rivers and oxbows. With a little help I was able to collect some clay in and around the Red River and the White River of Arkansas. I also experimented with shoveling up the various types of clays from my property and processing them like my ancient ancestors (Figures 4-5). My property's clay is like a sticky silty gumbo buckshot. It is black, full of silt, and I have to screen out small particles of manganese and limestone. I have found bone and pyrite in it too. However, this extremely silty clay has a tendency to want to crack in the fire. In my research I was able to talk to an Arkansas archaeologist named John Miller (Figure 6), who confirmed what I had suspected. The clay needed a temper that would help with the shrinkage and dehydration in the stress of firing. Traditionally we had used crushed bone and fired clay (grog), but that eventually evolved into the use of crushed mussel shell.

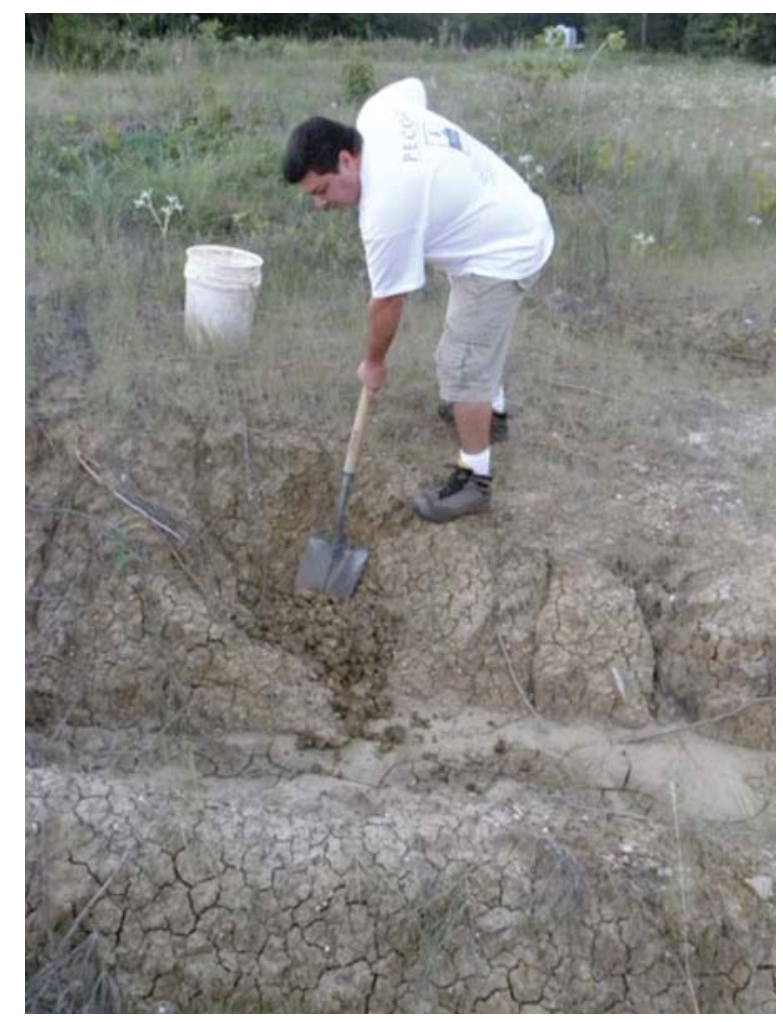

Figure 4. Digging Clay.

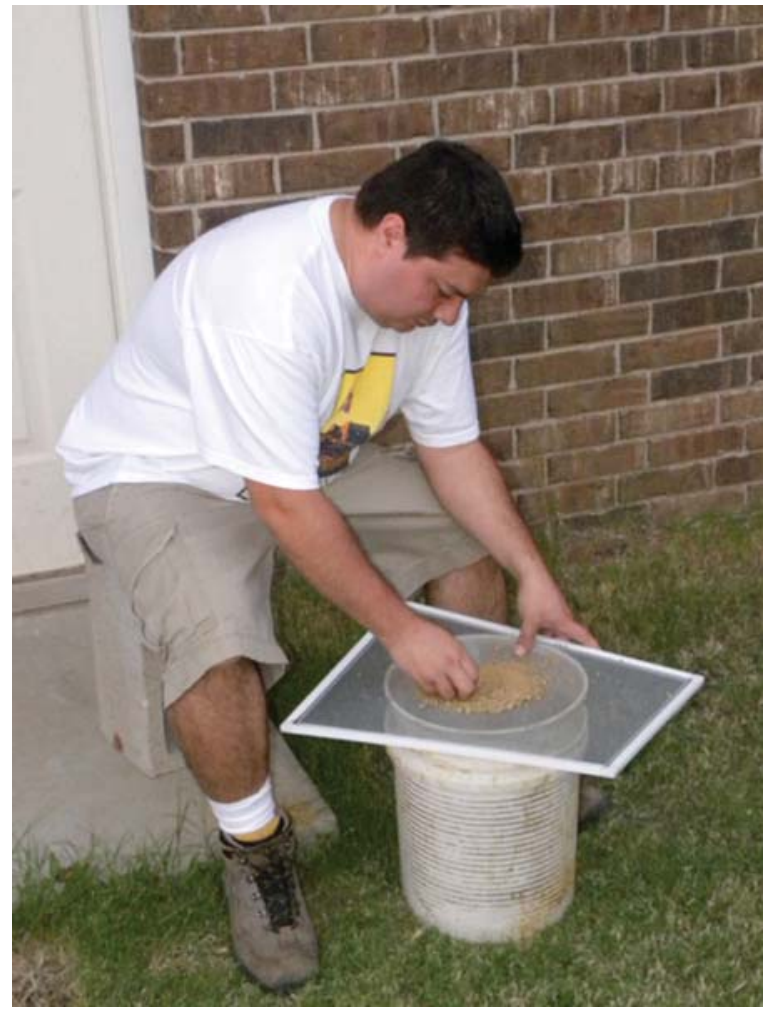

Figure 5. Hand Processing Clay. 


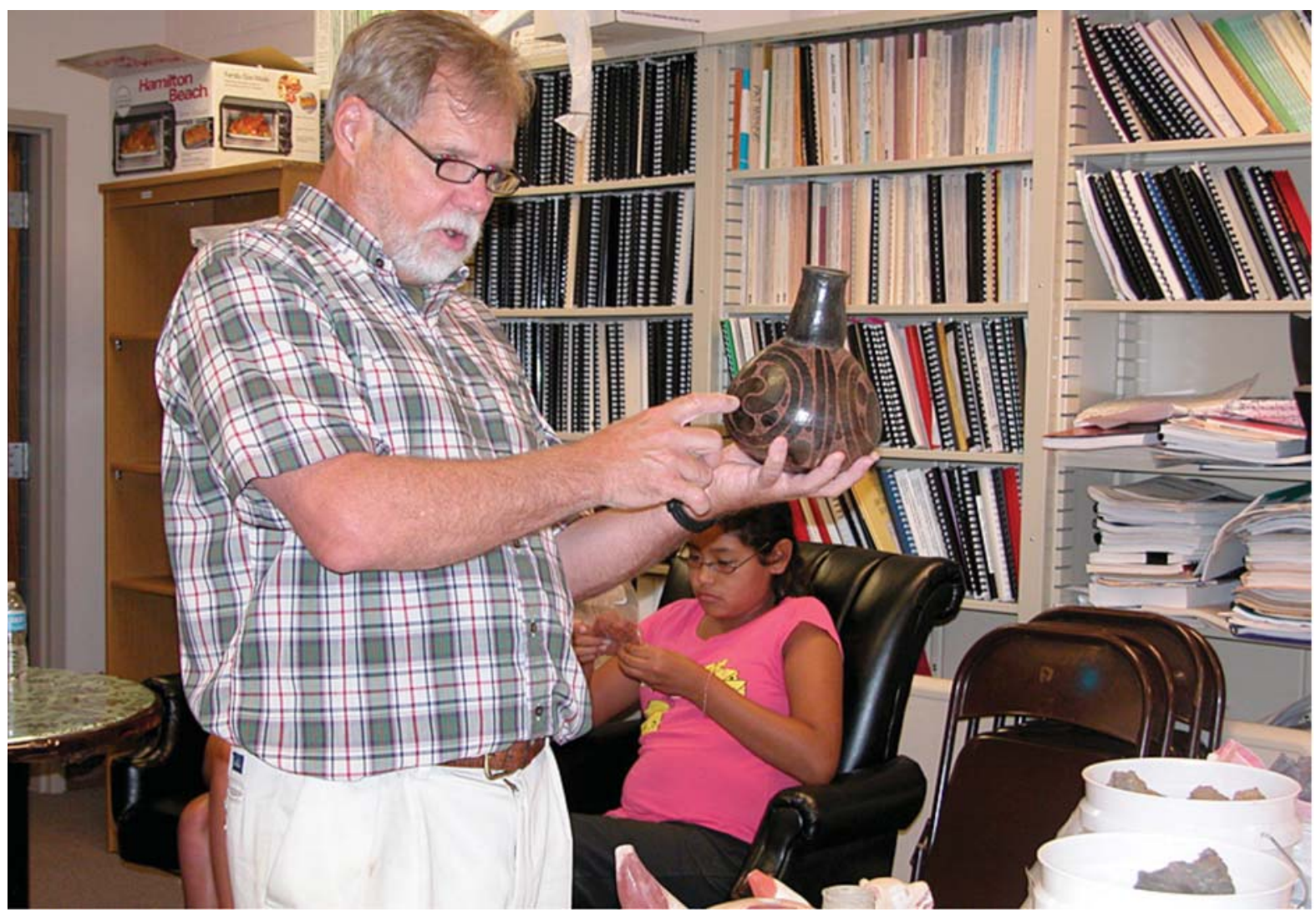

Figure 6. John Miller.

I decided to start out by using the mussel shell because I thought it would work the best and would be more accurately representative of our most familiar ancestral pottery (Figure 7). Sure enough, my first shelltempered clay pot survived the extreme firing without so much as a crack. That was also after I figured out how to fire properly. Originally I had dug a pit in my yard and had tried firing down within the cold damp earth. I quickly learned that not only was airflow cut off unless you engineer a more European draft pit, but also, my land's alpha water layer was quite high and flowed through the area quite often, filling in the pit with water almost daily from rain miles away. After researching more I soon realized that the Caddo's simply fired in a basic bonfire above ground, with a cone of wood (Figures 8-9). This was definitely easier than dealing with a mud hole, but I did have to adjust my fuel. It basically came down to gathering wood around my property and picking the best-sized sticks and twigs. Learning how to water smoke the pots around the fire was key in the success of many of my later firings. I could almost put the pot directly on the coals before building the wood teepee around it and letting the coals catch the fuel on fire. Learning about oxidation and reduction has been an area of interest for me as well. Along with the use of certain types of clays, I feel it is important to control the fire as much as possible to create the fully oxidized or partially reduced atmospheres in which the pots take on an intense red or deep chocolate brown color.

I feel like the design we use on the pots is another subject completely. Although the mixing and the formation is an art form in itself, it is more akin to sculpture and the physical manipulation of the earth. The forms follow behind a function that is reflected in the pot's creation. The design and the patterns we use on the pots themselves, to me, are more about a $2 \mathrm{D}$ graphical representation of a language and iconography (Figures 10-12). From what I have seen and felt from the many ancient pots, even going back to shell carvings, earlier societies liked to portray things in a very representational way (Figure 13). It is important to get the message across to the people on down the road. As the ages continue to roll on, these messages start to form a shorthand, as they are summarized graphically. This creates iconography as it is seen in many 


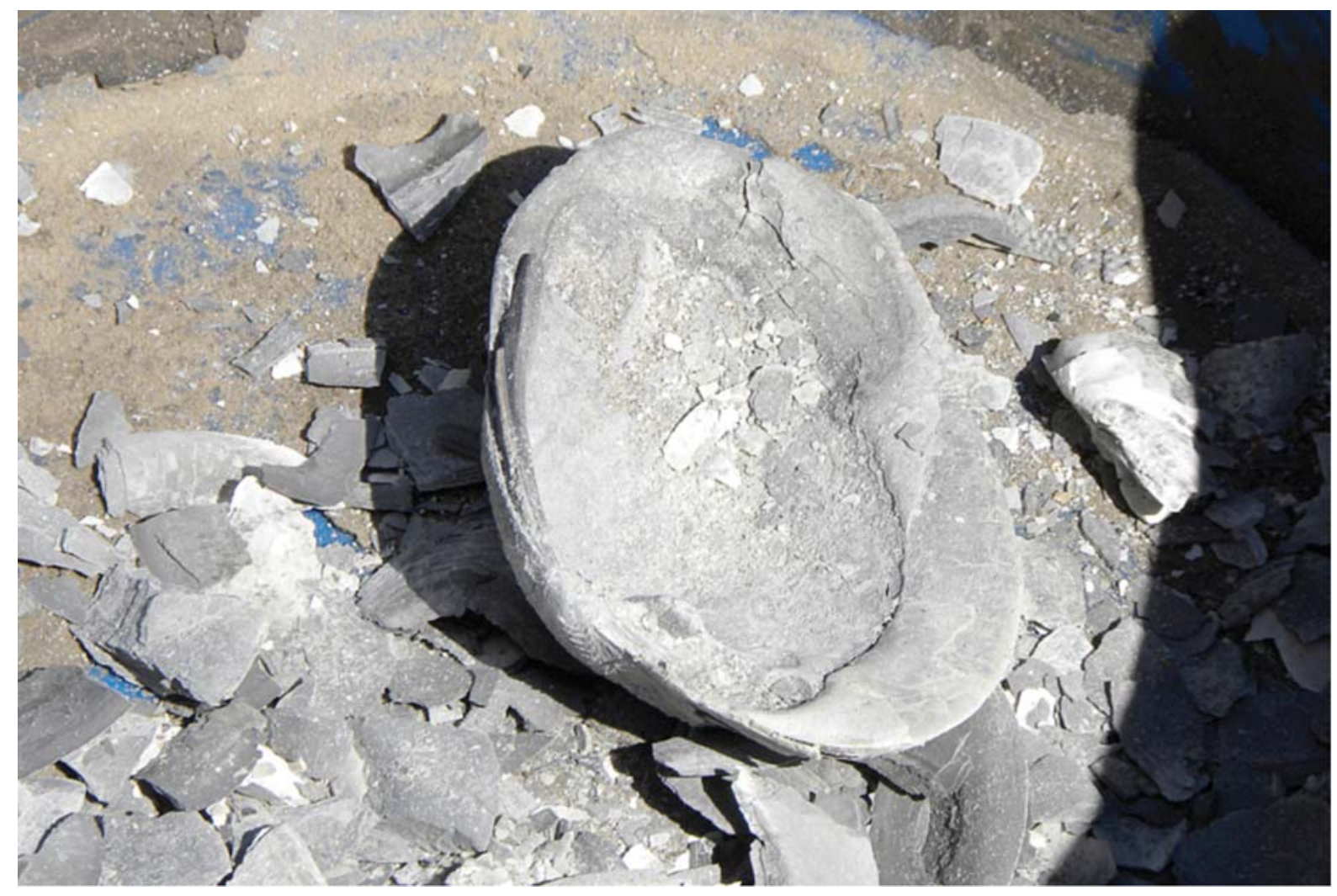

Figure 7. Crushed Mussel Shell.



Figure 8. Pit Fire of "Hadiku” (Black) bottle. 


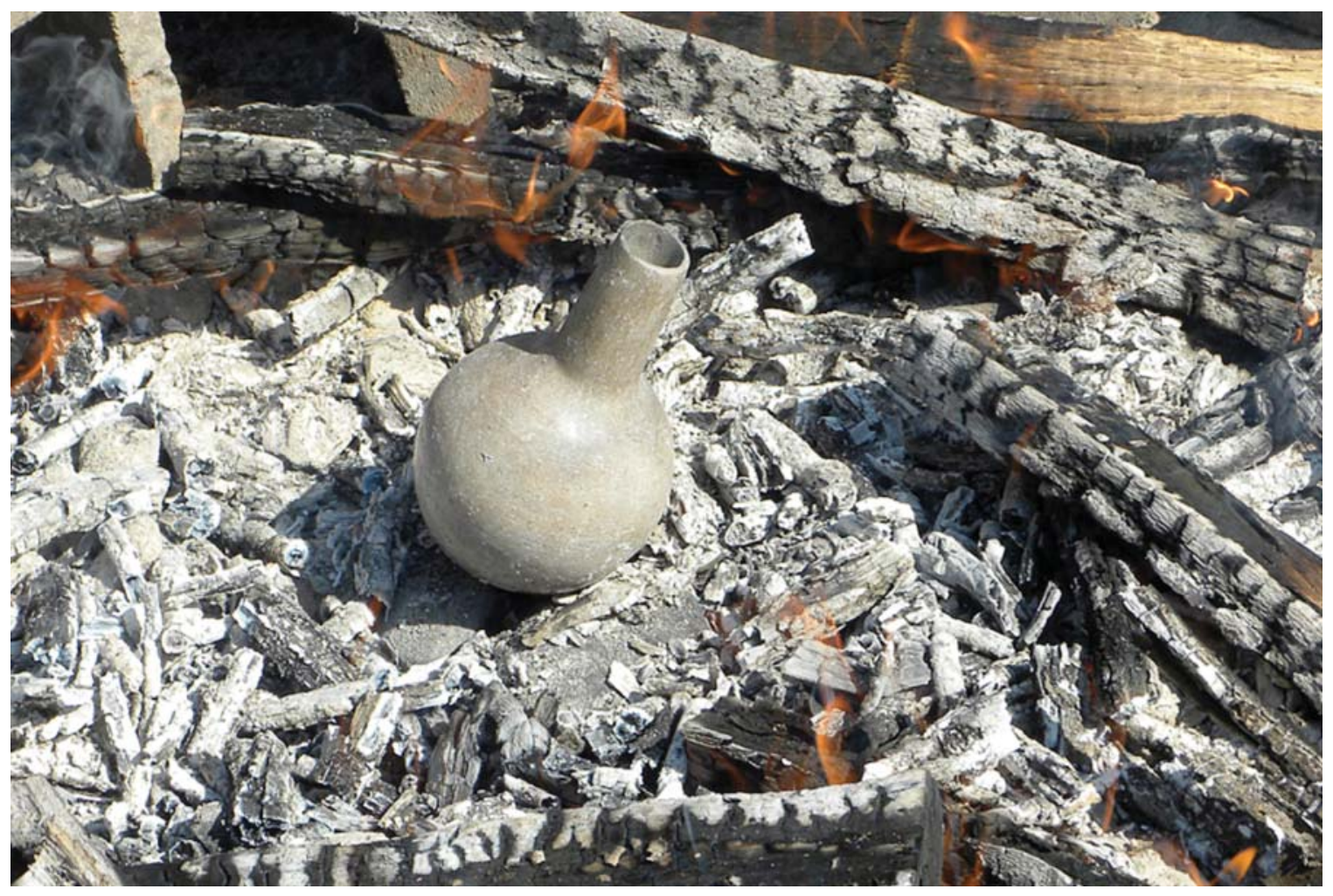

Figure 9. Pit Fire of "Nidahhih Hakaayu" (White River) bottle.

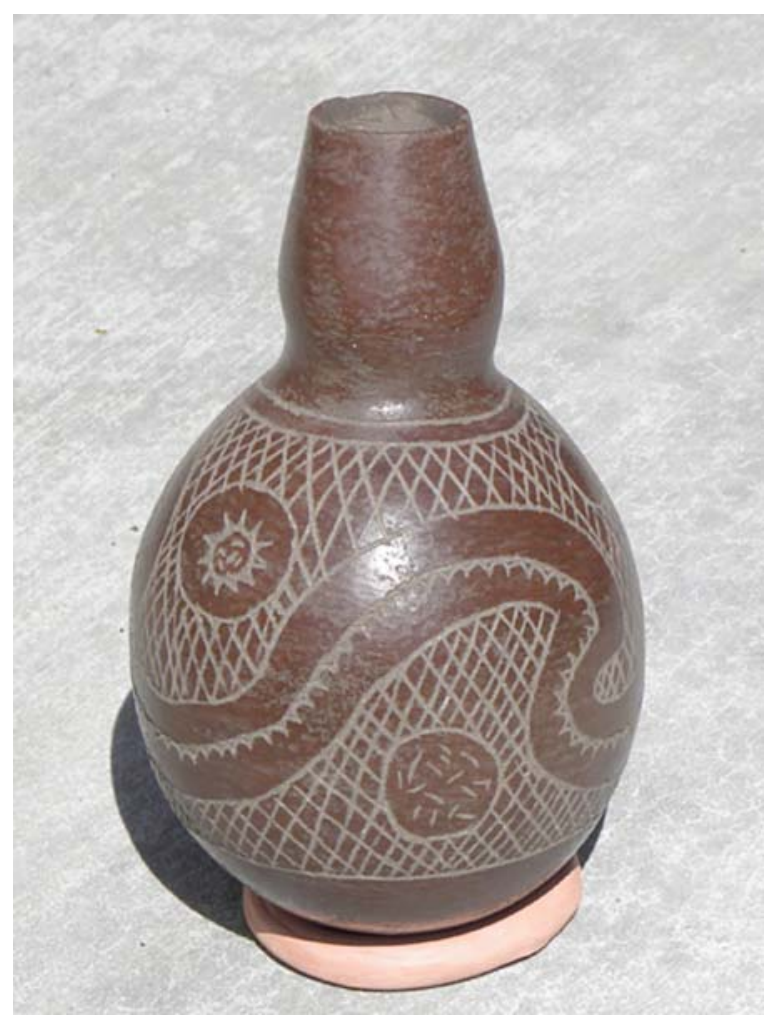

Figure 10. Fired Pot "Hadiku” (Black). 


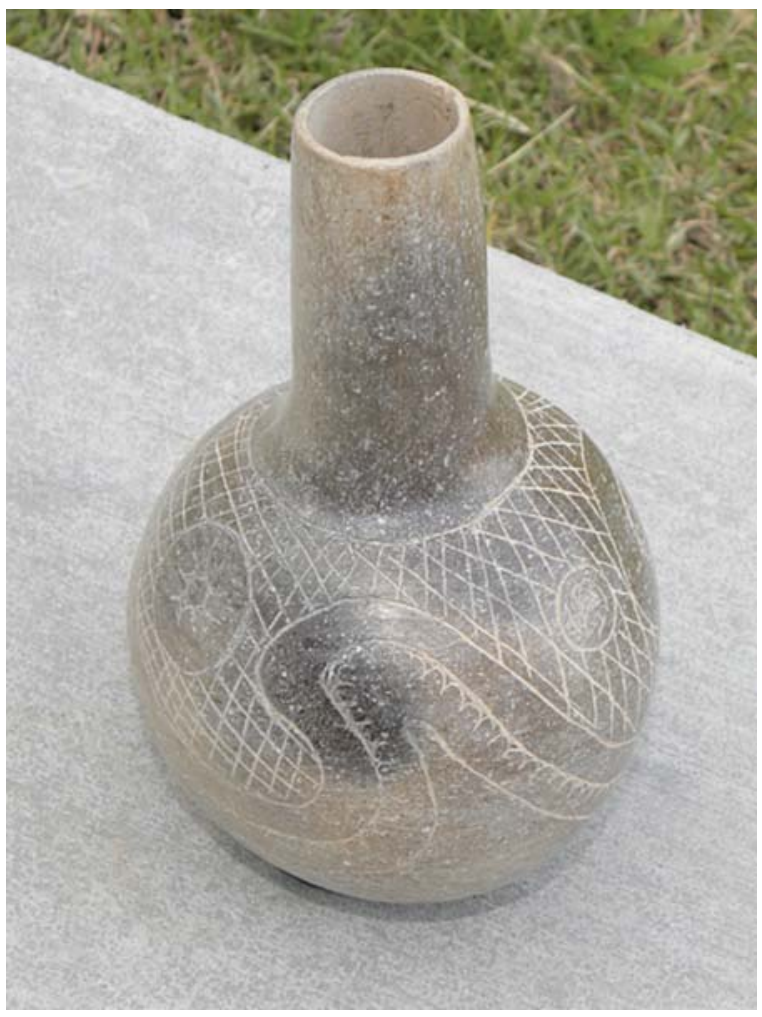

Figure 11. Fired Pot "Nidahhih Hikaayu" (White River).

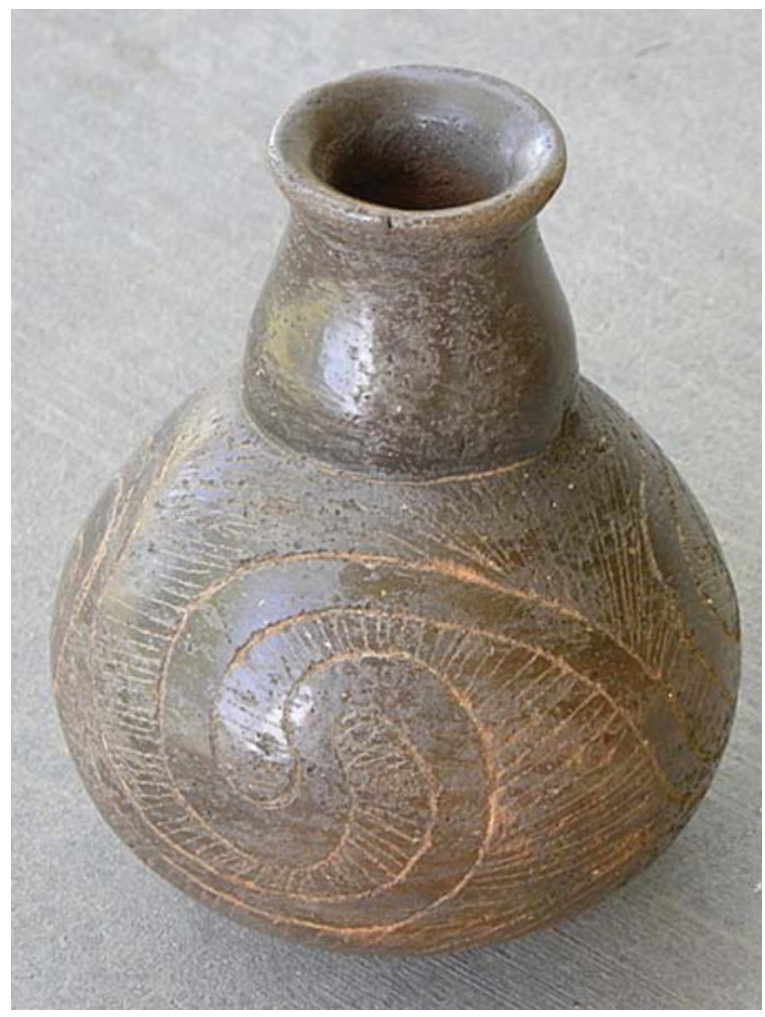

Figure 12. Fired Pot "Hakunu” (Brown).

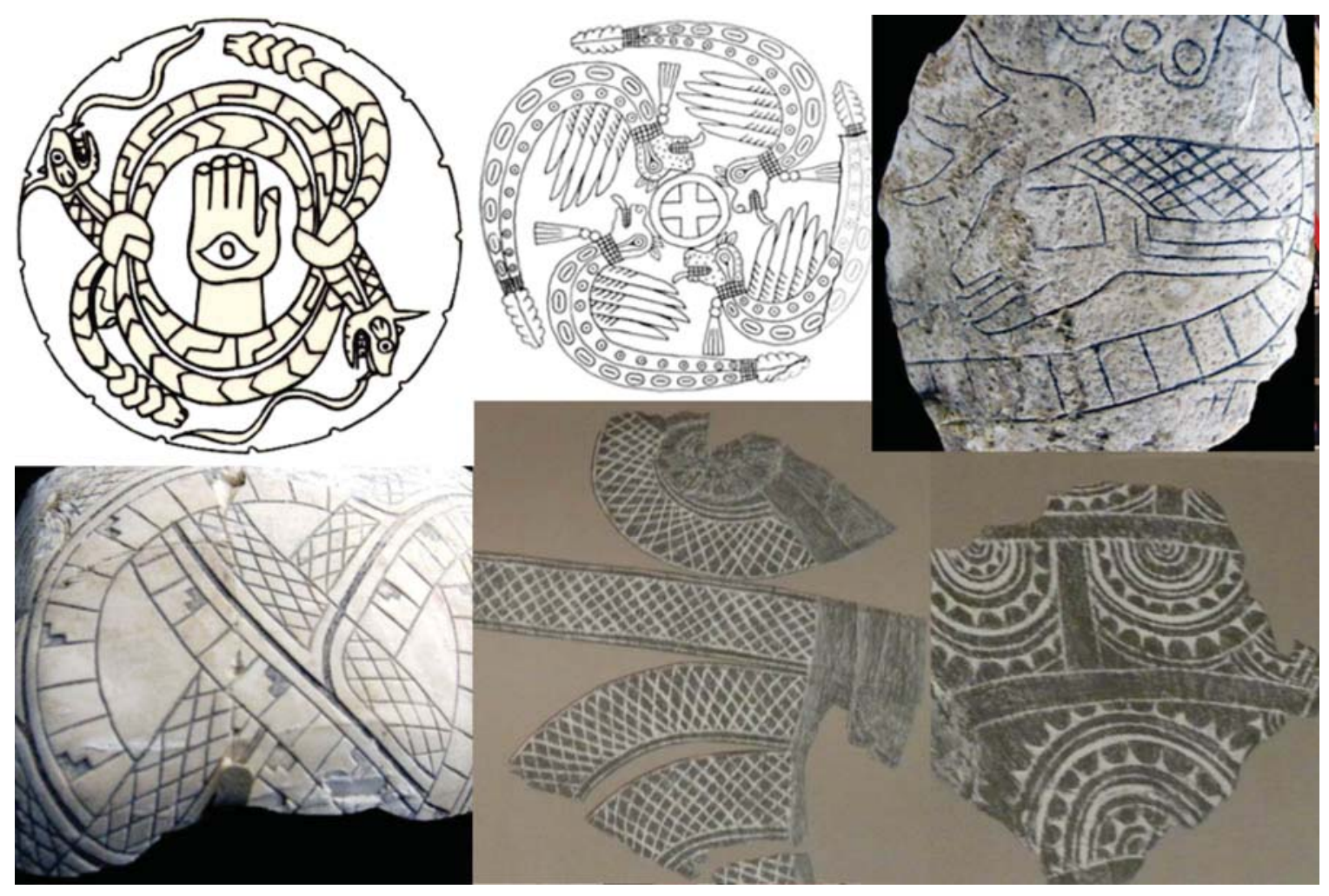

Figure 13. Representational to iconic designs. 
different cultures. Much like the traditional Caddo dance songs, words get repeated so many times, through time, that they get shortened and distorted. Sometimes the action of singing the dances and of carving the designs are more important than the original meaning from so long ago. In this way, I feel that the designs are these traditional words we repeat and we sing onto the pots' surfaces, whether it is about the turkey, the horned snake, or the panther, or any of our old tales. It is important to put these words down on the pot carefully, so that they may carry on into the future for the next generation. I do feel that our ancestors would have taken as much pride and asserted as much skilled control over the creation of this pottery as I would like to someday achieve. It is what I strive for. I let the beauty of the pots speak for themselves. 